\title{
From Productivity to Process: Flipping the Writing Group
}

\section{Dayna Jean DeFeo, PhD}

Senior Researcher, Center for Alaska Education Policy Research, University of Alaska Anchorage

Email: djdefeo@alaska.edu

Zeynep Kilıç, PhD

Associate Professor, Sociology, University of Alaska Anchorage

Corresponding Author Email: zkilic@alaska.edu

\section{Rebeca Maseda, PhD}

Associate Professor, Languages, University of Alaska Anchorage

Email: rebeca.maseda@alaska.edu

\section{Doi:10.5901/ajis.2016.v5n3s1p544}

\begin{abstract}
Although research productivity is the most important component in academic promotions, faculty are left on their own to excel, often without resources, sufficient support, or information. This isolated aspect of workloads can become oppressive and work against the outcome: scholarly productivity. This paper outlines the literature on writing groups, focusing on benefits in and outside of academia, and presents a case example of the authors' own writing group. It discusses a paradigm shift in the writing process as the group worked together: they moved from accountability to establishing healthy habits, from surveillance and punishment to self-care, and from external validation to intrinsic motivation by finding identities as writers.
\end{abstract}

Keywords: productivity, writing groups, academic writing, writing identity, collaboration

\section{Introduction}

We tell ourselves myths about writing (Boice, 2000), conceptualizing it as a solitary endeavor (Muller, 2014), difficult, mysterious, and magical, requiring inspiration from a muse. Or, we regard writing as insurmountable - a process demanding large blocks of time, requiring struggle and suffering. Or, we perceive the talent for writing is innate - we are born great writers (or not).

Many academics struggle with writing (Sorcinelli, 1998; Muller, 2014), and academics may be the most troubled writers (Schneider, 2003). Their self-identified barriers are diverse, including lack of time, workload issues, and fear about failing (Boice \& Jones 1984; Rickard et al., 2009; Steiniert, McLeod, Liben \& Snell, 2008). Schneider (2003) traces writing troubles to our process of indoctrination, suggesting we sustain the dissertation experience throughout our careers as the "committee in our head," a collection of everyone who has critiqued our writing.

We cannot fall prey to this. As academics, writing is one of our most salient responsibilities. Publications weigh heavily in hiring, promotion, and tenure; as higher education focuses on output tallying, it creates ontological insecurity through the publish-or-perish model (Elizabeth \& Grant, 2013). We realized that to thrive in this environment, we needed to deconstruct these myths, and this is where our writing group (WG) originated. This paper describes our process for creating an effective WG model, focusing on our realizations within that journey.

\section{Our WG Origins}

Our WG formed in the fall of 2012. We come from different backgrounds and academic disciplines; at first glance, we seem an unlikely group. When the WG was forming, Dayna had recently completed a PhD in Curriculum \& Instruction. Her goal was to move into a research or faculty position, and she knew she would need to develop a track record of publications. As an administrator in the learning center, she was neither recognized for nor encouraged to do research. Rebeca teaches Spanish language and culture in the Department of Languages, with a research agenda in film studies. 
She was missing intellectual stimulus and sought a community of researchers with whom to share ideas and to renew her passion for scholarship. Zeynep is a sociologist who was shifting her research focus. She was struggling with her transition to Alaska, and was unsure how to align her interests with her research agenda.

Despite outwardly different backgrounds, our goal was the same: to increase productivity. We all needed publications, and the WG was primarily conceptualized as an accountability strategy. Additionally, we needed support in navigating the university setting. Like many new faculty members (see Sorcinelli, 1998), we felt disillusioned: our interactions with colleagues were reduced to small talk. We longed for intellectual exchange.

We started with feedback meetings to review one another's pieces and provide individualized critique; meeting on alternate weeks, we each presented work every six weeks. However, we found ourselves scrambling at the last minute to produce pieces when our turn came up. To combat this, we incorporated a daily blog, adapted from Rockquemore's writing boot camp (National Center for Faculty Development \& Diversity, n.d.). Each day, we reported writing activities, how we rewarded ourselves for working, and our writing goal for the following day. The blog created daily accountability, and helped us set and hold one another to short-term goals. This ameliorated the issues of avoidance, and we saw a rapid increase in papers. Additionally, the blog became a place to chronicle our history, trajectory, and compiled resources.

After a year of meeting and blogging, we organized our first annual retreat to reflect on writing habits and set personal writing/research agendas. Using Boice's (1990) work, we reflected on fundamentals: audience, the submission and review process, writing blocks, and organizational strategies. We articulated our habits -good and bad - and how they affected our work. Though we had been writing together for a year, we had not considered these facets, and this self-discovery became an opportunity for us to learn about one another's writing processes, rather than our writing products (see also Murray \& Newton, 2009).

Understanding how we approach writing helped us both work more efficiently as individuals and support one another. Dayna will tinker with a paper incessantly, including more citations or repeatedly revising the language while realizing diminished returns. The WG responded by helping her set submission deadlines, interrupting the cycle of unproductiveness. Rebeca writes quickly, producing papers rapidly; however she loses steam and neglects some of the editing process. Here, the WG encouraged her in the opposite direction- to review papers more thoroughly before submission. Zeynep has a difficult time getting started, but once she begins, she gets into a groove and is exceptionally productive. For her, the WG encouraged her to start writing, and also helped to establish a healthier and regular writing schedule that limited binge-writing (Boice, 1990) and facilitated short-term goal-setting (see also Kearns, Gardiner \& Marshall, 2008). Knowing one another's needs became key to giving customized support, which strengthened our process.

Following our first retreat, we also considered the social aspects of the writing process. Responsively, we incorporated weekly write-on-site (WOS) meetings - a standing two-hour weekly meeting at a local coffee shop. Though we work on individual projects, this change of scenery and silent support diminishes the feelings of isolation that sometimes characterize the writing process.

Initially we were concerned that our interdisciplinary conglomerate would inhibit constructive feedback. As we worked together, we realized separation was a benefit. Because we were not in the same department or aspiring to the same journals, we had no competition, but the interdisciplinary feedback also helped us write more clearly and free of jargon. In reflection, this may have helped our grant applications, which are usually reviewed by multidisciplinary panels (see also Buissink-Smith, Hart \& van der Meer, 2013; Cuthbert et al., 2009).

The impact was a triplication of our research output (publications, grants, and conferences). As we reviewed literature around WGs in academia, we were surprised to find relatively little. Instructive publications are largely limited to writing theses and dissertations; for faculty writing, studies are almost exclusively limited to psychology and nursing (see Alonso 2007; Cumbie, Weinert, Luparell, Conley \& Smith, 2005; McGrail, Rickard \& Jones, 2006). Overall, though the literature documents benefits of WGs in academia (McGrail, Rickard \& Jones, 2006), there is not much empirical information about structuring or organizing them.

Though we encountered WG and writing strategy information in faculty blogs and op-ed pieces, we found more instructive works in the genre of creative writing. Table 1 provides an overview of WG models we identified in the literature, and we realized that we had intuitively combined several approaches Reading about different strategies and reflecting on our own process, we realized we had flipped the WG from its traditional presentation. With a mind to productivity, we developed mechanisms to facilitate accountability to manage increasing demands. However our activities and processes shifted our focus to habits, self-care, and identities as writers. The impact was ultimately an increase in productivity, but that was a byproduct of a shifted focus in process. Figure 1 depicts this evolution. 


\section{From Accountability to Healthy Habits}

Empirical studies about WGs report increased productivity (Alonso, 2007; Cumbie et al., 2005; Curtis, 2011; Muller, 2014; Ness, Duffy, McCallum \& Price, 2014; Sonnad, Goldsack \& McGowan, 2011; Steiniert et al., 2008; Stone, Levett-Jones, Harris \& Sinclair, 2010), and this was our initial interest. Several reasons are advanced for this outcome: WGs emphasize accountability (Alonso, 2007; Curtis, 2011; Muller, 2014), promote time management (Friend \& Gonzalez, 2009), and facilitate goal-setting by making writing a more structured and efficient enterprise (Cirasella \& Smale, 2011). Additionally, a strong sense of goals and commitment helps writers reframe blocks as states constructed by the writer (Boice, 1990; Nelson 1993), which thus can be deconstructed.

As untenured faculty and staff, we grappled with feelings of powerlessness: pressure to accept every miscellaneous department task or committee responsibility, and a lack of familiarity with institutional politics. Our experience was not unique; junior faculty frequently lack clarity around expectations and receive little feedback about their processes (Austin, 2002). Research and writing being largely independent, they are accountable to no one - until it is time to submit a tenure file. This vagueness and isolation can lead to significant morale drop (Sorcinelli \& Billings, 1993); unfortunately, the pressure and ensuing stress are antithetical to production.

In truth, productive authors do not have more free time (Boice \& Jones, 1984) or discipline (Schneider, 2003) than less productive ones, rather they approach the task differently. Productive writers in all genres cite a writing schedule. They set parameters in different ways, some bizarre, but regardless of method, regular writing is key, and maintaining forward momentum breeds productivity (Lehfeldt, 2015). Our blog forced time management and adherence to a writing schedule. It focused not on product (minutes writing or pages produced) but simply on writing every day. Its structure promoted short-term goal-setting with reasonable limits to avoid burnout. WOS also facilitated accountability and time management, requiring us to set fixed times for writing, and to make the act public.

The impact of these accountability strategies was the development of healthy writing habits. With clear goals and good habits, we found ourselves writing regularly, no longer relying on the accountability crutch. This outcome-oriented thinking and behavior aids in day-to-day wellbeing as it reinforces literary and therapeutic goals (Grundy, 2007). The key was identifying these goals and structuring writing to achieve them.

We each developed different writing schedules, writing at different times, in different places, and using different self-monitoring strategies. When we planned and scheduled daily time for writing, it became easier to maintain momentum. Ultimately, productivity did increase, but not simply from accountability. Rather, the processes we instituted helped us develop habits that forced us to work more efficiently and with intentionality. WG, then, simply reinforced these habits.

\section{From Surveillance to Self-Care}

Traditionally, academia has not regarded writing as a community effort (Mueller, 2014); isolation characterizes the profession (Austin, 2002). The public nature of writing for publication is a stressor for junior faculty who often receive no training in navigating the treacherous waters of academic publishing (Aitchison \& Lee, 2006). Prior to WG, our response to these challenges was self-surveillance (e.g., If I don't write, I can't have dessert), and pressure or guilt diminished the excitement of doing it (Elizabeth \& Grant, 2013). As we put off writing, then chastised ourselves, outcome was a downward spiral of self-deprecation.

WGs help break this cycle as they diminish isolation (Hara, 2009; Sorcinelli \& Elbow, 2006), improve collegial relationships (Cirasella \& Smale, 2011; Friend \& Gonzalez, 2009), and create a sense of belonging in an intellectual community (Buissink-Smith et al., 2013). WG membership facilitates a healthier approach as members replace selfdestructive ego maneuvers with self-care, thus facilitating creative processes (Nelson, 1993). Psychosocial benefits of WGs include developing a safe space (Grant \& Knowles, 2000; Grzybowski, Bates, Calam, Alred, Martin, \& Andrew, 2003) and forum to "exchange energy and ideas without fear of ridicule" (McGrail et al., 2006, p. 30), and helping members develop self-awareness to incorporate feedback (Grzybowski et al., 2003; Miller \& Muhlenkamp, 1989). Frequently described as a community of practice (Wenger 2001) WGs serve as peer support networks to facilitate development (see Bosanquet et al., 2014; Devenish et al. 2009; Murray \& Newton, 2009). This seems especially poignant for women and minority faculty (Burciaga \& Tavares, 2006; National Center for Faculty Development and Diversity, n.d.; Sonnad et al., 2011; Tierney \& Bensimon, 1996; Turner, 2004).

Setting up our WG, we knew we needed support - both to facilitate productivity, and to navigate our careers. We rotated meetings in our homes, and always had food for one another. This created a sense of intimacy, which established 
trust and solidarity. At first, we thought this trust was important so we could receive constructive feedback from one another; as we developed this relationship, we realized that the support nurtured far more than academic critiques.

With social support, we reframed our punitive approaches with positive thinking and rewards. We realized that our grueling work schedules had distanced us from personal interests, a phenomenon familiar to junior faculty (Sorcinelli, 1998). Thus in addition to our semester writing goals we also set personal ones (e.g., attending tango classes, biking to work, regular jogging), and we were just as encouraging with those commitments as the writing ones.

This self-care spurred us to focus on writing spaces and physical needs. We had previously regarded office decoration as too frivolous to merit attention, and resultantly, our offices were not places we wanted to be - much less work. We avoided them, instead working in spaces not designed for writing. Hunched over a laptop on the couch, Dayna and Zeynep developed backaches when they worked for long periods. This created a significant physical barrier to productive writing. Beautifying our offices and attending to our ergonomic needs helped us to spiritually and physically feel better when we wrote.

We learned the importance of recognizing accomplishments and celebrating successes (see Buissink-Smith, et al., 2013). Some celebrations are small, and some are more substantial, but the point is we pause to reflect and share the success with others who understand the meaning of the accomplishment. These celebrations reinforce our social bond and give us energy and encouragement to push through with work and responsibilities. This healthy self-care facilitates positive attitudes and nurtures capacity for productivity.

\section{From External Validation to Identities as Writers}

One of the most interesting outcomes of our WG was a need we had not recognized - enjoyment in our work that allowed us to stop relying on extrinsic validation. By setting clear goals, writing regularly, and exchanging support, WG members find pleasure in the act of writing (Nelson, 1993), which facilitates meaning-building (Leander \& Prior, 2004). With this mindset, WG members regard writing as a pleasure, rather than a chore (Schneider, 2003), and develop healthy affect (see Bosquet, 2014; Bryan \& Olsen 2003). Incorporating principles of mindfulness (Boice, 2000) helps develop a state of happiness and self-confidence, which are conducive to productivity (Curtis, 2011; Hara, 2009; Sonnad et. al, 2011).

When we first came to the WG, we had not reflected on who we were as writers - we regarded writing as a job duty. In retrospect, we had low feelings of self-efficacy. Zeynep was questioning whether she belonged in academia at all - she had internalized negative feedback she received from a mentor in graduate school, and allowed it to stymie her progress (see also McGrail, et al., 2006). Dayna was on the verge of abandoning writing while she performed administrator duties, because she could not find a way to incorporate it into her workload. Rebeca lacked opportunities to talk about her work with colleagues, and feelings of isolation stalled her curiosity; she needed confirmation that research was a worthy part of our job, rather than invisible and peripheral (Murray \& Newton, 2009). When we identified these needs in our retreats, we explored how we could use writing to connect to our passions, and how to reframe writing as a central part of our academic identities (see Gainen, 1993).

Our experiences were not unique; Sommers (cited in Schneider, 2003) notes that academic writing fails to bring life and writing together. Focusing on how writing could nurture our creative interests - not just pad our CVs - we shifted our approaches. First, we focused our research agendas, considering our work five to ten years into the future and building a scholarly agenda, rather than publishing isolated articles. By aligning our work with our passions, we found greater enjoyment and connectedness; therein, we started to acknowledge writing as a legitimate use of our time - equally valid as teaching or service. As we incorporated daily writing we found ourselves identifying as writers and scholars, which we had never done before (see also Murray \& Newton, 2009). When we developed a track record of publications, this confidence allowed us to undertake more rigorous projects.

As we pursued more competitive journals and grants, we had to reframe our response to rejections. With strong identities as writers and competent scholars, we were able to detach ourselves from the writing product (Boice, 1994), dissociating rejection or R\&Rs from self-worth, and no longer acquiescing our scholarly competence to an anonymous reviewer. When we stopped regarding the peer review process as a binary of success or failure, it no longer felt like a dehumanizing, soul-crushing experience (Hoelscher \& Werder, 2010a, 2010b). Our regard for ourselves and for one another as capable professionals overpowered the external review (see also Gainen, cited in McGrail, 2006).

With this healthier self-regard, support, and the successes we actualized, we became consistently more productive. The enjoyment of scholarship that initially defined our interest in academia was restored. Investment in what seemed to be non-academic aspects of the writing process resulted in greater confidence, control, and agency, along with higher job satisfaction. 


\section{Impact}

Because we work in a university that is teaching- and service-intensive, the WG is our antidote to the trap of putting off research. Our WG has been working together for over four years, and we have not lost momentum. When we recently met to set goals for the semester, we each expressed excitement about new projects and opportunities. This reflects changes in our process and products - not just in counts and tallies, but in the nature of the work we do.

First, our scholarly horizons have expanded - we have all branched into new research areas and taken our scholarship to a new level, publishing in more prestigious journals and getting more external grants. We also find ourselves more open to collaborative projects, coauthoring papers with colleagues for projects that previously would have fizzled after a conference presentation. We also co-authored with each other, noticing the overlaps among our fields.

As a result of working together, we are trying new things in our writing. When we became more familiar with one another's processes, we became inspired by their styles. Dayna's frequent use of diagrams and schematics, Zeynep's use of clever titles, and Rebeca's project management and organizational strategies have been adopted and adapted by all, making writing a more engaging and creative expression.

Pleasure for writing and a healthy regard for one's self as a writer may seem difficult to maintain in an environment that operates on criticism; we posit that a positive self-concept is the only way to thrive. Ultimately, our process made us happier, more engaged writers. As we focused more on process and less on product, we found that we had therein flipped the WG. Our initial goal of productivity became a happy byproduct of good habits, passion for our work, and clear identities as writers (see also Cuthbert et al. 2009).

\section{Conclusion}

A detrimental perspective on WGs is the perception that faculty who need social support and accountability checks are not suited to academia (see Muller, 2014). We could not disagree more. Though we came to the WG from a deficit paradigm, that view has been obliterated. The WG is not a crutch; at the end of the day, producing an article is, by and large, an individual endeavor. The WG did not write the papers, we did these on our own, just as we did before the WG. Rather, the WG gave us the structure, support, and discipline to enjoy writing and the motivation to do it more frequently. Our increased productivity was the result of a realignment of our scholarly and personal interests, and we are committed to maintaining this healthy balance.

\section{References}

Alonso, A. (2007). Reflections on the writing group. International Journal of Group Psychotherapy 57(2): 219-23.

Aitchison, C., \& Lee, A. (2006). Research writing: Problems and pedagogies. Teaching in Higher Education, 11(3), 265-278.

Austin, A. E. (2002). Creating a Bridge to the Future: Preparing New Faculty to Face Changing Expectations in a Shifting Context. The Review of Higher Education 26 (2): 119-144.

Boice, R. (1990). Professors as writers: A self help guide to productive writing. Stillwater, OK: New Forums Press.

Boice, R. (1994). How writers journey to comfort and fluency: A psychological adventure. New York, NY: Greenwood Publishing Group.

Boice, R. (2000). Advice for new faculty members: Nihil nimus. Boston, MA: Allyn and Bacon.

Boice, R. \& Jones, F. (1984). Why academicians don't write. Journal of Higher Education 55, 567-582.

Bosanquet, A., Cahir, J., Jacenyik-Trawoger, C., \& McNeill, M. (2014). From speed dating to intimacy: Methodological change in the evaluation of a writing group. Higher Education Research \& Development, 33(4), 635-648.

Bryan, S., \& Olsen, W. (2003). Planet on the table: Poets on the reading life. Louisville, KY: Sarabande Books.

Buissink-Smith, N., Hart, S. \& van der Meer, J. (2013). 'There are other people out there!' Successful postgraduate peer groups and research communities at a New Zealand university. Higher Education Research \& Development, 32(5), 695-705.

Burciaga, R., Tavares, A. (2006). Our pedagogy of sisterhood: A testimonio. In Bernal, D., Elenes, C., Godinez, F., \& Villenas, S. (Eds.), Chicana/Latina education in everyday life: Feminista perspectives on pedagogy and epistemology (133-142). Albany, NY: State University of New York Press.

Cirasella, J. \& Smale, M. A. (2011). Peers don't let peers perish: Encouraging research and scholarship among junior library Faculty. Collaborative Librarianship 3(2), 98-109.

Cumbie, S., Weinert, C., Luparell, S., Conley, V., \& Smith, J. (2005). Developing a scholarship community. Journal of Nursing Scholarship, 37(3), 289-293.

Curtis, C. (2011, March 24). The rules of writing group. The Chronicle of Higher Education. Retrieved from: https://chronicle.com/article/The-Rules-of-Writing-Group/126880/

Cuthbert, D., Spark, C., \& Burke, E. (2009). Disciplining writing: The case for multi-disciplinary writing groups to support writing for publication by higher degree by research candidates in the humanities, arts and social sciences, Higher Education Research \& 
Development, 28(2), 137-149.

Devenish, R., Dyer, S., Jefferson, T., Lord, L. van Leeuwen, S. \& Fazakerley, V. (2009) Peer to peer support: The disappearing work in the doctoral student experience, Higher Education Research \& Development, 28(1), 59-70.

Elizabeth, V. \& Grant, B. M. (2013). 'The spirit of research has changed': reverberations from researcher identities in managerial times. Higher Education Research \& Development, 32(1), 122-135.

Friend, J., \& González, J. C. (2009). Get together to write. Academe, 95(1), 31-33.

Gainen, J. (1993). A writing support program for junior women faculty. New Directions for Teaching and Learning, 1993(53), 91-100.

Grant, B. \& Knowles, S. (2000). Flights of imagination: Academic women be(com)ing writers. International Journal for Academic Development, 5(1), 6-19.

Grundy, D. (2007). What is a writing group? Dilemmas of the leader. International Journal of Group Psychotherapy, 57(2), $133-151$.

Grzybowski, S. C., Bates, J., Calam, B., Alred, J., Martin, R. E., \& Andrew, R. (2003). A physician peer support writing group. Family Medicine, 35(3), 195-201.

Hara, B. (2009, September 29). New faculty writing groups. Chronicle of Higher Education. Retrieved from http://chronicle.com/blogs/profhacker/new-faculty-writing-groups/22732

Hoelscher, K. \& Werder, C. (2010, September 10). Writing for academe: A series on dialogue, mentoring, and motivation. Inside Higher Ed. Retrieved from http://www.insidehighered.com/advice/hoelscher/hoelscher1

Hoelscher, K. \& Werder, C. (2010, October 20). Faculty writing workshop: Write now! Inside Higher Ed. Retrieved from http://www.insidehighered.com/advice/hoelscher/hoelscher3

Kearns, H., Gardiner, M. \& Marshall, K. (2008). Innovation in PhD completion: The hardy shall succeed (and be happy!). Higher Education Research \& Development, 27(1), 77-89.

Kern, S. (2011) Analytic model for academic research productivity having factors, interactions and implications. Cancer Biology \& Therapy, 12(11), 949-956.

Leander, K. \& Prior, P. (2004). Speaking and writing: How talk and text interact in situated practices. In Bazerman, C. \& Prior, P. (Eds.), What writing does and how it does it: An introduction to analyzing texts and textual practices. Mahwah, NJ: Lawrence Erlbaum.

Lehfeldt, E. A. $(2015, \quad$ January 2). Something/anything: Momentum. Retrieved from https://talesoutofschoolblog.wordpress.com/2015/01/02/somethinganything-momentum/

Maher, M. A., Feldon, D. F., Timmerman, B. E. \& Chao, J. (2014). Faculty perceptions of common challenges encountered by novice doctoral writers. Higher Education Research \& Development, 33(4), 699-711.

McGrail, M., Rickard, C. \& Jones, R. (2006). Publish or perish: A systematic review of interventions to increase academic publication rates. Higher Education Research \& Development, 25(1), 19-35.

Miller, B. K. \& Muhlenkamp, A. (1989). Teaching students how to publish in nursing journals: A group approach. Journal of Nursing Education (28), 379-38.

Muller, E. L. (2014). Developing the faculty as a writing community. Academe, 100(6), 34-38.

Murray, M. \& Newton, M. (2009) Writing retreat as structured intervention: Margin or mainstream? Higher Education Research \& Development, 28(5), 541-553.

National Center for Faculty Diversity (n.d.). Faculty success program. Retrieved from http://www.facultydiversity.org/

Nelson, V. (1993). On writer's block: A new approach to creativity. New York, NY: Houghton Mifflin Company.

Ness, V., Duffy, K., McCallum, L., \& Price, L. (2014). Getting published: Reflections of a collaborative writing group. Nurse Education Today, 34(1), 1-5.

Rickard, C. M., McGrail, M., Jones, R., O'Meara, P., Robinson, A., Burley, M. \&, Ray-Barruel, G. (2009). Supporting academic publication: Evaluation of a writing course combined with writers' support group. Nurse Education Today, 29(5), 516-521.

Schneider, P. (2003). Writing alone and with others. New York, NY: Oxford University Press.

Sonnad S. S., Goldsack J., \& McGowan K. L. (2011). A writing group for female assistant professors. Journal of the National Medical Association, 103(9-10), 811-815.

Sorcinelli, M. D. (1998). Satisfactions and concerns of new university teachers. To improve the academy, 121-133.

Sorcinelli, M. D. \& Billings, D. A. (1993). The career development of pretenure faculty: An institutional study. Paper presented at AERA conference. Retrieved from: http://files.eric.ed.gov/fulltext/ED359875.pdf

Sorcinelli, M. D. \& Elbow, P. (2006). The faculty writing place: A room of our own. Change: The Magazine of Higher Learning, 38(6), 1722. Retrieved from: http://works.bepress.com/marydeane_sorcinelli/25

Steiniert, Y., McLeod, P. J., Liben, S. \& Snell, L. (2008). Writing for publication in medical education: The benefits of a faculty development workshop and peer writing group. Medical Teacher, 30(8), e280-e285.

Stone, T., Levett-Jones, T., Harris, M., \& Sinclair, P. M. (2010). The genesis of 'the neophytes': A writing support group for clinical nurses. Nurse Education Today, 30(7), 657-661.

Tierney, W. G., \& Bensimon, E. M. (1996). Promotion and tenure: Community and socialization in academe. SUNY Press.

Turner, C.S.V. (2004, November.) Hiring faculty of color: Research on the search committee process and implications for practice. Paper presented at the Keeping Our Faculty conference, University of Minnesota, Minneapolis, MN.

Wenger, E. (2001). Communities of practice: Learning, meaning, and identity. New York, NY: Cambridge University Press. 


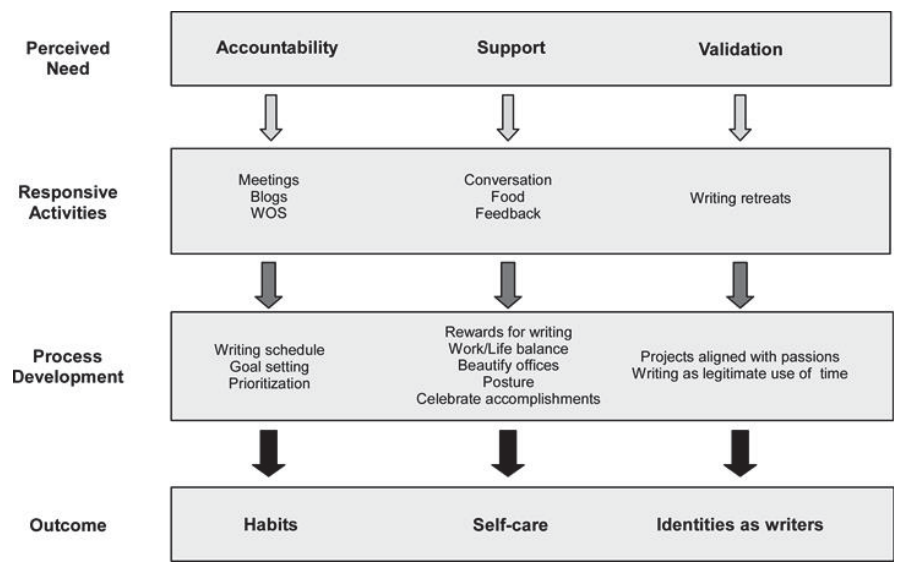

Note: We started the WG to meet our perceived needs, but as we worked together, we developed processes that supported productivity.

Figure 1: Flipping the writing group

\section{Table 1: Writing Group Models}

\begin{tabular}{|c|c|c|c|c|c|}
\hline & Traditional WG & Writing Accountability Group & Write-On-Site & Online WG & Coaches \& Nags \\
\hline Description & $\begin{array}{l}\text { Small group has regular, } \\
\text { meetings to read and critique } \\
\text { one another's work }\end{array}$ & $\begin{array}{l}\text { Small group meets weekly and } \\
\text { members articulate: last week's } \\
\text { goals, progress, challenges, goals } \\
\text { for coming week }\end{array}$ & $\begin{array}{l}\text { At scheduled times, group } \\
\text { members come to a } \\
\text { designated space to write }\end{array}$ & $\begin{array}{l}\text { Participants commit to daily } \\
\text { writing, report daily activities, } \\
\text { track progress over time, and } \\
\text { engage in discussion }\end{array}$ & $\begin{array}{l}\text { Coach provides consultations to } \\
\text { develop productive strategies; nag } \\
\text { calls to initiate writing and checks } \\
\text { in to verify progress }\end{array}$ \\
\hline Function & Provide substantive feedback & $\begin{array}{l}\text { Create social contract; support, } \\
\text { accountability, peer mentoring }\end{array}$ & $\begin{array}{l}\text { Creates interruption-free } \\
\text { space for regular writing; } \\
\text { minimizes feelings of } \\
\text { isolation }\end{array}$ & $\begin{array}{l}\text { Provides support, accountability, } \\
\text { and tracks progress over time; } \\
\text { may incorporate feedback }\end{array}$ & $\begin{array}{l}\text { Provides "push" to write on a } \\
\text { regular basis }\end{array}$ \\
\hline Commitment & $\begin{array}{l}\text { Meeting time; provide } \\
\text { comments; produce and share } \\
\text { work regularly }\end{array}$ & $\begin{array}{l}\text { Regular meetings; report and } \\
\text { follow-through on stated goals }\end{array}$ & $\begin{array}{l}\text { Regular attendance; } \\
\text { coordinate meeting space }\end{array}$ & $\begin{array}{lr}\text { Regular attendance } \quad \begin{array}{r}\text { and } \\
\text { participation; }\end{array} \\
\text { relationships; nurture } \\
\text { organization }\end{array}$ & Cost; regular contact \\
\hline Pros & $\begin{array}{l}\text { Social pressure to produce } \\
\text { pieces for discussion; feedback } \\
\text { provided at all stages of writing } \\
\text { process }\end{array}$ & $\begin{array}{l}\text { Social pressure to report progress; } \\
\text { members can have diverse goals }\end{array}$ & $\begin{array}{l}\text { Variable group sizes; } \\
\text { members can have diverse } \\
\text { goals }\end{array}$ & $\begin{array}{l}\text { Asynchronous interactions; } \\
\text { connects writers across } \\
\text { geographic spaces }\end{array}$ & $\begin{array}{l}\text { Push comes from neutral third } \\
\text { party, instead of friends or } \\
\text { colleagues }\end{array}$ \\
\hline Cons & $\begin{array}{l}\text { Interests and abilities must } \\
\text { align sufficiently to provide } \\
\text { meaningful feedback; limited } \\
\text { daily accountability }\end{array}$ & $\begin{array}{l}\text { Feedback focuses on habits over } \\
\text { content; members must show } \\
\text { commitment and follow-through; } \\
\text { no critique or sharing }\end{array}$ & $\begin{array}{l}\text { Projects must be portable; } \\
\text { no critique or sharing; } \\
\text { productive use of time is } \\
\text { individually monitored }\end{array}$ & $\begin{array}{l}\text { Commercial groups may charge } \\
\text { membership; online platform can } \\
\text { make it easier to ignore } \\
\text { deadlines }\end{array}$ & Cost; may not motiv \\
\hline
\end{tabular}

Note. Awareness of one's needs, expectations of other members, and ability to commit to the WG allows individuals to identify the model best suited to their goals and objectives. 